\title{
Eksistensi Sektor Pertanian dalam Struktur Perekonomian Kabupaten Bangli
}

\author{
I PUTU YOGA DARMAJAYA, I GUSTI AYU OKA SURYAWARDANI, \\ I GUSTI AGUNG AYU AMBARAWATI
}

\author{
Program Studi Agribisnis, Fakultas Pertanian, Universitas Udayana \\ Jalan PB. Sudirman Denpasar, 80323 \\ Email: yoga.darmajaya.pt@gmail.com \\ gungdani@gmail.com
}

\begin{abstract}
The Existence of Agricultural Sector in Bangli Regency Economic Structure

Contribution of agricultural sector to economy of Bangli Regency has decreased during 2011-2015 with relatively slow growth. This condition indicates that there has been a structural transformation of the economy, therefore it is necessary to analyze the existence of agricultural sector in terms of its current and future role whether it is still a leading sector or will turn into non-leading sectors. This study uses secondary data in the form of Gross Regional Domestic Product (GRDP) by industry of Bangli Regency and Bali Province in 2011-2015. The data were collected by using document study and analyzed by Location Quotient, Dynamic Location Quotient and Total Shift Share method. The results showed that the agricultural sector is the basis sector in Bangli Regency today and in the future. While the sub sectors in agricultural sector that become the basis is seasonal horticultural crops, annual horticulture and other crops, livestock and forestry and logging. Sub sectors in agriculture sector which are predicted to change the role in the future are food crops, annual plantation and fishery that changes role become basis sector were caused by the location factor. While the annual horticulture sub-sector and livestock are changed into non-basis sub-sectors were caused by the economic structure factor.
\end{abstract}

Keywords: agricultural sector, basis sector, location quotient, dynamic location quotient, total shift share

\section{Pendahuluan}

\subsection{Latar Belakang}

Kegiatan pembangunan yang dilakukan di negara-negara berkembang lebih ditekankan pada pembangunan ekonomi, hal ini disebabkan karena terjadinya keterbelakangan ekonomi. Pembangunan di bidang ekonomi dapat mendukung pencapaian tujuan atau mendorong perubahan-perubahan atau pembaharuan bidang kehidupan lainnya (Siagian, 1984). Diberlakukannya kebijakan otonomi daerah di Indonesia yang menetapkan bahwa pemerintah daerah menjalankan otonomi yang seluas-luasnya untuk mengatur dan mengurus sendiri urusan pemerintahan berdasarkan asas otonomi dan tugas pembantuan, menyebabkan pembangunan daerah menjadi penting peranannya. Hal ini dikarenakan kegiatan pembangunan 
langsung dilaksanakan oleh daerah berdasarkan potensi pengembangan dimiliki tiaptiap daerah. Menurut Sanjaya (2009), pembangunan ekonomi daerah merupakan bagian integral dari pembangunan nasional yang diarahkan untuk memacu pemerataan pembangunan dan hasil-hasilnya dalam rangka menciptakan peluang kerja bagi masyarakat sehingga dapat meningkatkan kesejahteraan masyarakat serta mendukung peningkatan taraf hidup dan kualitas hidup masyarakat daerah.

Salah satu sektor ekonomi yang masih diandalkan dalam pembangunan ekonomi daerah di Indonesia yang merupakan negara agraris adalah sektor pertanian karena sektor pertanian memiliki peran penting dalam pembangunan ekonomi nasional baik dari segi pendapatan maupun penyerapan tenaga kerja. Pembangunan pertanian di Indonesia dianggap penting dari keseluruhan pembangunan nasional. Ada beberapa hal yang mendasari mengapa pembangunan pertanian di Indonesia mempunyai peranan penting antara lain, potensi sumber daya alam yang besar dan beragam, pangsa terhadap pendapatan nasional cukup besar, besarnya pangsa terhadap ekspor nasional, besarnya penduduk Indonesia yang menggantungkan hidupnya pada sektor ini, perannya dalam penyediaan pangan masyarakat dan menjadi basis pertumbuhan di pedesaan. Potensi pertanian Indonesia yang besar namun pada kenyataannya sampai saat ini sebagian besar petani masih banyak yang termasuk golongan miskin. Hal ini mengindikasikan bahwa pemerintah pada masa lalu bukan saja kurang dalam memberdayakan petani tetapi juga terhadap sektor pertanian secara keseluruhan (Gadang, 2010).

Kabupaten Bangli merupakan salah satu kabupaten di Provinsi Bali yang masih mengandalkan sektor pertanian dalam pembangunan ekonominya karena sektor pertanian merupakan sektor strategis yang mempunyai kaitan erat dengan upaya mengatasi pengangguran, usaha membangun ketahanan pangan dan basis pembangunan ekonomi daerah. Walaupun pertumbuhan sektor pariwisata di Bali dan Kabupaten Bangli khususnya semakin meningkat, sektor pertanian masih menjadi penyumbang pendapatan daerah tertinggi dengan kontribusi sebesar 25,47\% dari total pendapatan daerah atau PDRB Kabupaten Bangli.

Selama tahun 2011-2015 kontribusi sektor pertanian, kehutanan dan perikanan terus mengalami penurunan. Tahun 2011 kontribusi sektor pertanian, kehutanan dan perikanan sebesar 27,79\% kemudian mengalami penurunan tiap tahunnya dan di tahun 2015 kontribusinya menjadi 25,47 \%. Laju pertumbuhan sektor pertanian, kehutanan dan perikanan juga cenderung berfluktuasi dan relatif lambat. Hal ini menunjukkan bahwa adanya kecenderungan terjadinya proses transformasi struktural perekonomian dan perubahan atau pergeseran peran sektor perekonomian di Kabupaten Bangli. Oleh karena itu, perlu dilakukan analisis mengenai eksistensi yang dilihat dari peranan sektor dan sub sektor pertanian saat ini maupun di masa mendatang apakah masih menjadi sektor yang unggul atau akan mengalami perubahan peranan menjadi sektor bukan unggulan. 


\subsection{Rumusan Masalah}

Sesuai dengan latar belakang yang telah diuraikan, maka yang menjadi rumusan masalah dalam penelitian ini adalah sebagai berikut :

1. Apakah peranan sektor pertanian dan sektor lainnya terhadap perekonomian Kabupaten Bangli ?

2. Apakah terjadi perubahan peranan sektor pertanian pada masa yang akan datang dalam perekonomian di Kabupaten Bangli?

3. Faktor apakah yang menyebabkan terjadinya perubahan peranan sektor dan sub sektor pertanian dalam perekonomian Kabupaten Bangli?

\subsection{Tujuan Penelitian}

Sesuai dengan latar belakang yang telah diuraikan, maka tujuan dari penelitian ini adalah untuk mengetahui :

1. Peranan sektor pertanian dan sektor lainnya dalam perekonomian Kabupaten Bangli.

2. Perubahan peranan sektor dan sub sektor pertanian pada masa yang akan datang dalam perekonomian di Kabupaten Bangli.

3. Faktor yang menyebabkan terjadinya perubahan peranan sektor sektor pertanian dalam perekonomian Kabupaten Bangli.

\section{Metode Penelitian}

\subsection{Lokasi dan Waktu Penelitian}

Penelitian ini dilakukan di Kabupaten Bangli. Pengambilan data penelitian dilakukan mulai bulan Mei-Juni 2017. Pemilihan Lokasi penelitian dilakukan dengan sengaja menggunakan metode purposive sampling.

\subsection{Jenis dan Sumber Data}

Jenis data yang digunakan dalam penelitian ini yaitu (1) data kualitatif yang digunakan dalam penelitian ini adalah gambaran umum Kabupaten Bangli dan (2) data kuantitatif yang digunakan dalam penelitian ini adalah data Produk Domestik Regional Bruto (PDRB) menurut lapangan usaha Provinsi Bali dan Kabupaten Bangli. Sumber data dalam penelitian ini, yaitu data sekunder yang bersumber dari Badan Pusat Statistik (BPS) Kabupaten Bangli dan Provinsi Bali.

\subsection{Metode Pengumpulan Data}

Metode pengumpulan data yang digunakan dalam penelitian ini adalah studi dokumen. Menurut Sugiyono (2007) studi dokumen adalah teknik pengumpulan data dengan meneliti berbagai dokumen yang akan digunakan sebagai bahan analisis. Dokumen yang digunakan dalam penelitian ini adalah Produk Domestik Regional Bruto Kabupaten Bangli dan Provinsi Bali tahun 2011-2015. 


\subsection{Jenis dan Pengukuran Variabel}

Menurut Antara (2006) variabel dapat diartikan sebagai sesuatu yang akan menjadi objek pengamatan penelitian yang mempunyai nilai bervariasi.Variabel dalam penelitian ini adalah identifikasi sektor pertanian dan identifikasi sub-sub sektor pertanian dengan indikator PDRB Kabupaten Bangli dan Provinsi Bali yang dianalisis menggunakan metode LQ, DLQ dan TSS.

\subsection{Metode Analisis Data}

\subsubsection{Location quotient}

Metode Location Quotient (LQ) menurut Widodo (2006) adalah mengukur konsentrasi dari suatu kegiatan (industri) dalam suatu daerah dengan cara membandingkan perannya dalam perekonomian daerah itu dengan peran kegiatan atau industri sejenis dalam perekonomian regional atau nasional.

\subsubsection{Dynamic location quotient}

Dynamic Location Quotient (DLQ) adalah metode analisis yang digunakan untuk mengetahui terjadinya suatu perubahan posisi terhadap sektor pertanian di Kabupaten Bangli. DLQ adalah suatu metode yang digunakan untuk mengatasi kelemahan metode LQ yang bersifat statis sehingga dapat diketahui reposisi atau perubahan sektoral dengan mengintroduksikan laju pertumbuhan dengan asumsi bahwa setiap nilai tambah sektoral ataupun PDRB mempunyai rata-rata laju pertumbuhan pertahun sendiri-sendiri dalam kurun waktu tahun awal dan tahun berjarak (Sambodo dalam Sanjaya, 2009).

\subsubsection{Total shift share}

Menurut Suyatno (2000) metode LQ maupun DLQ hanya menunjukkan posisi dan reposisi sektoral dalam pertumbuhan ekonomi daerah tanpa membahas sebab perubahan tersebut. Maka untuk mengetahui penyebab perubahan dapat digunakan analisis Total Shift Share (TSS), dengan persamaan TSS $=\Sigma$ (gn-gin)Xino $+\Sigma($ GiG)Xino $+\Sigma($ gin-Gi)Xino. Persamaan $\Sigma$ (gn-gin)Xino $+\Sigma($ Gi-G)Xino merupakan komponen Structural Shift Share (SSS) dan persamaan $\Sigma$ (gin-Gi)Xino merupakan komponen Locational Shift Share (LSS), dengan ketentuan jika nilai SSS > TSS maka faktor struktur ekonomi yang mempengaruhi perubahan yang terjadi sedangkan jika nilai SSS < LSS maka faktor lokasi adalah yang mempengaruhi perubahan yang terjadi.

\section{Hasil dan Pembahasan}

\subsection{Analisis Identifikasi Sektor Perekonomian dan Sub Sektor dalam Sektor Pertanian}

\subsubsection{Identifikasi sektor pertanian dan sektor perekonomian lainnya}

Mengidentifikasi sektor pertanian dan sektor lainnya yang merupakan sektor basis dilakukan dengan metode analisis LQ. Hasil dari analisis LQ untuk sektor 
pertanian dan sektor perekonomian lainnya di Kabupaten Bangli tahun 2011-2015 dapat dilihat pada Tabel 1.

Tabel 1.

Nilai LQ Sektor Perekonomian Kabupaten Bangli Tahun 2011-2015

\begin{tabular}{|c|c|c|c|}
\hline Kategori & Lapangan Usaha & $\begin{array}{l}\text { Rata-rata } \\
\text { LQ }\end{array}$ & Ket \\
\hline A & Pertanian, Kehutanan, dan Perikanan & 1,74 & Basis \\
\hline $\mathrm{B}$ & Pertambangan dan Penggalian & 2,00 & Basis \\
\hline $\mathrm{C}$ & Industri Pengolahan & 1,44 & Basis \\
\hline $\mathrm{D}$ & Pengadaan Listrik dan Gas & 0,15 & Non basis \\
\hline $\mathrm{E}$ & $\begin{array}{l}\text { Pengadaan Air, Pengelolaan Sampah, } \\
\text { Limbah dan Daur Ulang }\end{array}$ & 0,29 & Non Basis \\
\hline $\mathrm{F}$ & Konstruksi & 0,80 & Non Basis \\
\hline $\mathrm{G}$ & $\begin{array}{l}\text { Perdagangan Besar dan Eceran; Reparasi } \\
\text { Mobil dan Sepeda Motor }\end{array}$ & 1,14 & Basis \\
\hline $\mathrm{H}$ & Transportasi dan pergudangan & 0,17 & Non basis \\
\hline I & Penyedia Akomodasi dan Makan Minum & 0,59 & Non basis \\
\hline $\mathrm{J}$ & Informasi dan Komunikasi & 0,75 & Non basis \\
\hline K & Jasa Keuangan dan Asuransi & 0,62 & Non basis \\
\hline $\mathrm{L}$ & Real Estate & 0,72 & Non basis \\
\hline $\mathrm{M}, \mathrm{N}$ & Jasa Perusahaan & 0,51 & Non basis \\
\hline $\mathrm{O}$ & $\begin{array}{l}\text { Administrasi Pemerintahan, Pertahanan } \\
\text { dan Jaminan Sosial Wajib }\end{array}$ & 2,14 & Basis \\
\hline $\mathrm{P}$ & Jasa Pendidikan & 0,45 & Non basis \\
\hline Q & Jasa Kesehatan dan Kegiatan Sosial & 0,66 & Non Basis \\
\hline $\mathrm{R}, \mathrm{S}, \mathrm{T}, \mathrm{U}$ & Jasa Lainnya & 1,80 & Basis \\
\hline
\end{tabular}

Sumber : BPS Provinsi Bali dan Kabupaten Bangli (2011-2015) (data diolah)

Sektor pertanian merupakan sektor basis di Kabupaten Bangli. Hal ini dapat dilihat dari nilai rata-rata LQ sektor pertanian yang lebih besar dari satu (Tabel 1). Mampunya sektor pertanian menjadi basis di Kabupaten Bangli karena didukung oleh kondisi iklim, penggunaan lahan dan jenis tanah yang sangat mendukung untuk aktivitas pertanian. Sektor-sektor perekonomian lainnya yang menjadi basis adalah sektor pertambangan dan penggalian, sektor industri pengolahan, sektor perdagangan besar dan eceran, reparasi mobil dan sepeda motor, sektor administrasi pemerintahan, pertahanan dan jaminan sosial wajib, serta sektor jasa lainnya, sedangkan sebelas sektor lainnya dikategorikan dalam sektor non basis karena memiliki nilai LQ yang lebih kecil dari satu.

\subsubsection{Identifikasi sub sektor dalam sektor pertanian}

Hasil dari analisis LQ untuk sub-sub sektor dalam sektor pertanian di Kabupaten Bangli tahun 2011-2015 dapat dilihat pada Tabel 2. 
Tabel 2.

Nilai LQ Sub Sektor dalam Sektor Perekonomian Kabupaten Bangli Tahun 2011-2015

\begin{tabular}{llcc}
\hline Sub Sektor Pertanian, Kehutanan dan Perikanan & $\begin{array}{c}\text { Rata- } \\
\text { rata } \\
\text { (LQ) }\end{array}$ & Ket \\
\hline 1 Pertanian, Peternakan, Perburuan dan Jasa & & \\
Pertanian & 0,68 & Non basis \\
a. Tanaman Pangan & 2,42 & Basis \\
b. Tanaman Hortikultura Semusim & 0,27 & Non basis \\
c. Perkebunan Semusim & 2,24 & Basis \\
d. Tanaman Hortikultura Tahunan dan Lainnya & 0,48 & Non basis \\
e. Perkebunan Tahunan & 1,40 & Basis \\
f. Peternakan & 0,53 & Non basis \\
g. Jasa Pertanian dan Perburuan & 4,88 & Basis \\
Kehutanan dan Penebangan Kayu & 0,38 & Non basis \\
\hline
\end{tabular}

Sumber : BPS Provinsi Bali dan Kabupaten Bangli (2011-2015) (data diolah)

Berdasarkan hasil analisis LQ, sub-sub sektor dalam sektor pertanian yang merupakan basis meliputi sub sektor tanaman hortikultura semusim dengan komoditas unggulan kubis dan bawang merah, sub sektor tanaman hortikultura tahunan dengan komoditas unggulan jeruk dan pisang, sub sektor peternakan yang meliputi ternak besar, ternak kecil dan ternak unggas dan sub sektor kehutanan dan penebangan kayu dengan komoditas unggulan kayu albesia dan bambu. Sub-sub sektor tersebut mampu menjadi sub sektor basis disebabkan oleh kontribusi sub-sub sektor tersebut terhadap perekonomian Kabupaten Bangli lebih besar dibandingkan kontribusi sub sektor tersebut terhadap perekonomian Provinsi Bali. Sub-sub sektor non basis dalam sektor pertanian meliputi sub sektor tanaman pangan, sub sektor perkebunan semusim, sub sektor perkebunan tahunan, sub sektor jasa pertanian dan perburuan serta sub sektor perikanan.

\subsection{Analisis Perubahan Peranan Sektor Pertanian dan Sub sektor dalam Sektor Pertanian}

\subsubsection{Analisis perubahan peranan sektor pertanian}

Hasil analisis DLQ menunjukkan bahwa sektor pertanian memiliki nilai lebih besar dari satu yaitu 1,70. Hal ini berarti bahwa sektor pertanian tidak mengalami perubahan posisi, sehingga sektor pertanian di Kabupaten Bangli masih menjadi sektor basis yang dapat diunggulkan di masa yang akan datang hal ini disebabkan karena laju pertumbuhan sektor pertanian, kehutanan, dan perikanan Kabupaten Bangli lebih cepat dibandingkan laju pertumbuhan sektor pertanian, kehutanan dan perikanan di Provinsi Bali. Laju pertumbuhan sektor pertanian yang cepat 
disebabkan karena Kabupaten Bangli memiliki keunggulan geografis berupa iklim dan keadaan tanah yang sangat mendukung pengembangan sektor pertanian.

\subsubsection{Analisis perubahan peranan sub sektor dalam sektor pertanian}

Hasil analisis DLQ sub sektor dalam sektor pertanian dapat dilihat pada Tabel 3.

Tabel 3.

Nilai DLQ Sub Sektor Pertanian Kabupaten Bangli

\begin{tabular}{|c|c|c|c|c|}
\hline \multicolumn{2}{|r|}{$\begin{array}{l}\text { Sub Sektor Pertanian, Kehutanan, } \\
\text { dan Perikanan }\end{array}$} & \multirow[t]{2}{*}{ LQ } & \multirow[t]{2}{*}{ DLQ } & \multirow[t]{2}{*}{ Keterangan } \\
\hline 1 & $\begin{array}{l}\text { Pertanian, Peternakan, } \\
\text { Perburuan dan Jasa Pertanian }\end{array}$ & & & \\
\hline & a. Tanaman Pangan & 0,68 & 1,74 & Non Basis menjadi Basis \\
\hline & $\begin{array}{l}\text { b. Tanaman Hortikultura } \\
\text { Semusim }\end{array}$ & 2,42 & 9,35 & Tetap Basis \\
\hline & c. Perkebunan Semusim & 0,27 & 0,23 & Tetap Non Basis \\
\hline & $\begin{array}{l}\text { d. Tanaman Hortikultura } \\
\text { Tahunan dan Lainnya }\end{array}$ & 2,24 & 0,16 & Basis menjadi Non Basis \\
\hline & e. Perkebunan Tahunan & 0,48 & 3,21 & Non Basis menjadi Basis \\
\hline & f. Peternakan & 1,4 & 0,81 & Basis menjadi Non Basis \\
\hline & g. Jasa Pertanian dan Perburuan & 0,53 & 0,60 & Tetap Non Basis \\
\hline 2 & $\begin{array}{l}\text { Kehutanan dan Penebangan } \\
\text { Kayu }\end{array}$ & 4,88 & 1,02 & Tetap Basis \\
\hline 3 & Perikanan & 0,38 & 1,07 & Non Basis menjadi Basis \\
\hline
\end{tabular}

Sumber : BPS Provinsi Bali dan Kabupaten Bangli (2011-2015) (data diolah)

Seperti terlihat pada Tabel 3 hasil analisis DLQ terhadap sub-sub sektor dalam sektor pertanian menunjukkan bahwa terdapat beberapa sub sektor yang mengalami perubahan peranan di masa yang akan datang yang meliputi sub sektor tanaman pangan, sub sektor perkebunan tahunan dan sub sektor perikanan yang merupakan sub sektor non basis berubah peranan menjadi sub sektor basis di masa yang akan datang. Hal ini disebabkan oleh laju pertumbuhan sub sektor tersebut di Kabupaten Bangli lebih cepat dibandingkan laju pertumbuhan sub sektor yang sama di Provinsi Bali, sedangkan sub sektor tanaman hortikultura tahunan dan sub sektor peternakan yang merupakan sub sektor basis berubah peranan menjadi sub sektor non basis di masa yang akan datang yang disebabkan oleh laju pertumbuhan sub sektor tersebut di Kabupaten Bangli lebih lambat dibandingkan laju pertumbuhan sektor tersebut di tingkat Provinsi Bali. 
Melambatnya laju pertumbuhan sub sektor tanaman hortikultura tahunan disebabkan karena produksi komoditas unggulannya mengalami penurunan yang disebabkan perubahan cuaca dan serangan hama penyakit (Dinas Pertanian, Ketahanan Pangan dan Perkebunan, 2016), sedangkan lambatnya pertumbuhan sub sektor peternakan disebabkan oleh penurunan jumlah ternak besar dan ternak kecil yang diusahakan di Kabupaten Bangli.

\subsection{Analisis Faktor Penentu Perubahan Peranan Sub Sektor dalam Sektor Pertanian}

Hasil dari analisis TSS untuk sektor pertanian di Kabupaten Bangli dapat dilihat pada Tabel 4 .

Tabel 4.

Faktor Penentu Perubahan Posisi Sub Sektor Pertanian di Kabupaten Bangli

\begin{tabular}{lccc}
\hline $\begin{array}{l}\text { Sub sektor } \\
\text { pertanian }\end{array}$ & $\begin{array}{c}\text { SSS } \\
\text { (Juta Rupiah) }\end{array}$ & $\begin{array}{c}\text { LSS } \\
\text { (Juta Rupiah) }\end{array}$ & Faktor Penentu \\
\hline $\begin{array}{l}\text { Tanaman pangan } \\
\begin{array}{l}\text { Tanaman } \\
\text { hortikultura } \\
\text { tahunan }\end{array}\end{array}$ & $-2.937,29$ & $18.485,52$ & Faktor lokasi \\
$\begin{array}{l}\text { Perkebunan } \\
\text { tahunan }\end{array}$ & $398.759,53$ & $-364.574,23$ & $\begin{array}{c}\text { Faktor struktur } \\
\text { ekonomi }\end{array}$ \\
$\begin{array}{l}\text { Peternakan } \\
\text { Perikanan }\end{array}$ & $-47.215,37$ & $52.944,18$ & Faktor lokasi \\
\hline Sumber :BPS Provinsi Bali dan Kabupaten Bangli (2011-2015) (data diolah)
\end{tabular}

Hasil analisis TSS menunjukkan bahwa perubahan peranan sub sektor tanaman pangan, perkebunan tahunan, dan perikanan disebabkan oleh faktor lokasi. Kabupaten Bangli yang memiliki keunggulan iklim dan jenis tanah merupakan lokasi strategis dalam pengembangan sektor pertanian terutama perkebunan tahunan dan tanaman pangan, selain itu Kabupaten Bangli juga mempunyai sumberdaya perairan yang sangat luas yaitu danau batur sangat cocok dikembangkan untuk komoditas perikanan darat. Perubahan peranan sub sektor tanaman hortikultura tahunan dan peternakan disebabkan oleh faktor struktur ekonomi. Perubahan struktur perekonomian Kabupaten Bangli dari sektor primer menuju sektor sekunder dan tersier dan menurunnya kontribusi sektor primer (pertanian) secara langsung mempengaruhi perkembangan sub sektor tanaman hortikultura tahunan dan sektor perternakan. 


\section{Simpulan dan Saran}

\subsection{Simpulan}

Berdasarkan hasil penelitian dan pembahasan yang telah diuraikan, maka dapat disimpulkan sebagai berikut.

1. Berdasarkan analisis LQ, selama tahun 2011-2015 sektor pertanian merupakan sektor basis di Kabupaten Bangli. Sub-sub sektor dalam sektor pertanian yang menjadi basis ekonomi selama tahun 2011-2015 adalah sub sektor tanaman hortikultura semusim, sub sektor tanaman hortikultura tahunan dengan komoditas, sub sektor peternakan, serta sub sektor kehutanan dan penebangan kayu. Sektorsektor perekonomian lainnya yang menjadi sektor basis adalah sektor pertambangan dan penggalian, sektor industri pengolahan, sektor perdagangan besar dan eceran; reparasi mobil dan sepeda motor, sektor administrasi pemerintahan, pertahanan dan jaminan sosial wajib, dan sektor jasa lainnya.

2. Berdasarkan analisis DLQ sektor pertanian tidak mengalami perubahan di masa mendatang dan tetap menjadi sektor basis di Kabupaten Bangli, sedangkan untuk sub sektor dalam sektor pertanian terjadi perubahan peranan pada beberapa sub sektor yaitu sub sektor tanaman pangan, perkebunan tahunan dan perikanan dari sub sektor non basis saat ini dapat diharapkan menjadi sub sektor basis dimasa mendatang, sub sektor tanaman hortikultura tahunan dan peternakan berubah peranan dari sektor basis saat ini diperkirakan menjadi sub sektor non basis di masa yang akan datang.

3. Faktor penyebab berubahnya peranan sub sektor tanaman pangan, perkebunan tahunan dan perikanan adalah faktor lokasi. Tersedianya lahan merupakan salah satu faktor yang mendukung pengembangan sub sektor tanaman pangan dan perkebunan. Sub sektor perikanan masih memiliki potensi pengembangan karena Kabupaten Bangli memiliki sumber daya perairan berupa Danau Batur yang masih dapat dimaksimalkan. Perubahan peranan pada sub sektor tanaman hortikultura tahunan dan peternakan menjadi non basis disebabkan oleh faktor struktur ekonomi. Struktur perekonomian Kabupaten Bangli cenderung bertransformasi kearah perekonomian sekunder dan tersier menyebabkan kontribusi sektor pertanian khusunya sub sektor tanaman hortikultura tahunan dan peternakan mengalami penurunan.

\subsection{Saran}

Berdasarkan hasil pembahasan dan kesimpulan yang diperoleh maka saran yang dapat disampaikan dapam penelitian sebagai berikut.

1. Pemerintah Kabupaten Bangli hendaknya melakukan upaya khusus dalam penanganan hama dan penyakit yang menyerang komoditas hortikultura tahunan yang menyebabkan terjadinya penurunan produksi komoditas unggulan seperti komoditas jeruk dan pisang.

2. Perlu adanya perluasan dan pemetaan dalam pemanfaatan Danau Batur sebagai sentra budidaya perikanan mengingat potensi pengembangan usaha budidaya yang masih sangat luas. 


\section{Ucapan Terimakasih}

Ucapan terimakasih penulis tujukan kepada semua pihak yang telah membantu penulis dalam melaksanakan penelitian hingga karya ilmiah ini dapat dipublikasikan dalam e-journal.

\section{Daftar Pustaka}

Antara, M. 2006. Bahan Ajar Mata Kuliah Metode Penelitian Agribisnis. Program Studi Magister, Program Pasca Sarjana Universitas Udayana: Denpasar.

Badan Pusat Statistik Kabupaten Bangli. 2016. Produk Domestik Regional Bruto Kabupaten Bangli Menurut Lapangan Usaha 2011- 2015. Bangli: Badan Pusat Ststistik Kabupaten Bangli.

Badan Pusat Statistik Provinsi Bali. 2016.Produk Domestik Regional Bruto Provinsi Bali Menurut Lapangan Usaha 2011- 2015. Denpasar: Badan Pusat Ststistik Provinsi Bali.

Dinas Pertanian, Ketahanan Pangan dan Perikanan Kabupaten Bangli. 2016. RenstraPD Dinas Pertanian, Ketahanan Pangan dan Perikanan Tahun 2016-2021.

Gadang, D. 2009. Analisis Peranan Sektor Pertanian terhadap Perekonomian Jawa Tengah (Pendekatan Analisis Input-output). Skripsi Fakultas Ekonomi. Universitas Diponegoro. Semarang.

Sugiyono. 2007. Metode Penelitian Bisnis. Cetakan Kesepuluh. Alfabeta. Bandung.

Widodo, T. 2006. Perencanaan Pembangunan : Aplikasi Komputer (Era Otonomi Daerah). UPP STIM YKPN. Yogyakarta.

Sanjaya, M. N. R. 2009. Aplikasi Locationt Quotient dan Shift Share Analysis Terhadap Peranan Sektor Pertanian di Kabupaten Bungo Provinsi Jambi. Skripsi Mahaiswa Fakultas Pertanian. Universitas Sebelas Maret. Surakarta.

Siagian, S. P. 1984. Pengembangan sumber daya insani. Gunung Agung.

Suyatno, 2000. Analisa Economic Base terhadap Pertumbuhan Ekonomi Daerah Tingkat II Wonogori : Menghadapi Implementasi UU No. 22/1999 dan UU No. 25/1999. Jurnal Ekonomi PembangunanVol. 1.No. 2 Hal. 144-159. Surakarta: UMS. 